\title{
EDITORIAL
}

\section{INVESTIGACIÓN CRÍTICA DE LA HISTORIA DE ENFERMERÍA}

$\mathrm{C}^{1}$ estudio de la historia nos permite aprender del pasado, comprender el y hacemos. Investigar la historia de enfermería nos lleva a la búsqueda reflexiva y crítica de cómo nuestra profesión reaccionó frente a los movimientos sociales, respondió a las hegemonías, vivenció los desastres y avanzó en su desarrollo como disciplina. Nos exige cuestionarnos y re-pensar. No se trata de una mera recolección cronológica de información. El estudio de la historia de nuestra profesión, a nivel local, nacional y latinoamericano, ilumina el presente y nos plantea nuevos desafíos. Nos revela el origen de la mayoría de los problemas sociales que vivimos hoy, pues muchos fenómenos son cíclicos y tienden a repetirse, cambiando de forma, pero manteniendo su esencia. Los historiadores nos señalan que la historia permite cohesión e identidad a los grupos, les permite definirse y mantenerse con valores propios. Motivarnos a reconstruir críticamente esta historia profesional es ineludible, para la comprensión de lo que somos hoy, del reconocimiento social que gozamos, de nuestras aspiraciones y búsquedas de lo que aún nos queda por alcanzar. 